\title{
Upaya Meningkatkan Kemampuan Menggunakan Program Power Point Dalam Pembelajaran Teknologi Informasi Dan Komunikasi (Tik) Melalui Praktik Membuat Presentasidi Kelas Vii F Smp Negeri 1 Kabupaten Sorong
}

\author{
Suleman Gais Mareti \\ SMP Negeri 1 Kabupaten Sorong \\ Email: gais6415@gmail.com
}

\begin{abstract}
: this classroom action research aimed to improve students' understanding on the theory of power point program and to improve their ability in using power point program through making presentation. The result shown an improvement. Before action, the average score of students who got complete score was 75 that was 8 students from 32 students or $25 \%$. On the action of cycle I, it improved to be 10 students from 32 students or 31,25\%. On the action of cycle II, it increased to be 12 students or $37,5 \%$. Based on the result, it could be concluded that the application of cooperative learning strategy and optimizing learning media could improve the students learning result especially on TIK Subject at standard competency of making application program based on presentation in solving problem of comparison with scale at SMP Negeri 1 Sorong Regency.
\end{abstract}

Keywords: power point program, presentation, IT Subject, students' understanding, SMP Negeri 1 Sorong Regency

\begin{abstract}
Abstrak: Penelitian ini bertujuan untuk meningkatkan pemahaman siswa terhadap teori mengenai program power point serta untuk meningkatkan kemampuan siswa dalam menggunakan program power point melalui praktik membuat presentasi. Berdasarkan hasil penelitian diperoleh hasil bahwa telah terjadi peningkatan hasil perbaikan pembelajaran. Sebelum perbaikan, siswa yang tuntas dengan nilai rata-rata 75 ada 8 siswa dari 32 siswa atau 25\%. Pada perbaikan siklus I meningkat menjadi 10 siswa dari 32 siswa atau 31,25\%. Kemudian pada perbaikan siklus II lebih meningkat lagi menjadi 12 siswa dari 32 atau 37,5\%. Melalui perbaikan pembelajaran ternyata sangat diperlukan dalam proses pembelajaran. Dari hasil perbaikan yang telah dilaksanakan oleh guru dapat disimpulkan bahwa proses pembelajaran dengan menerapkan strategi pembelajaran Cooperative Learning, serta mengoptimalkan media pembelajaran dapat lebih meningkatkan hasil belajar siswa khususnya pelajaran TIK tentang standar kompetensi melakukan pembuatan program aplikasi berbasis presentasi dalam pemecahan masalah perbandingan dengan skala, indikator memecahkan masalah skala di SMP Negeri 1 Kabupaten Sorong.
\end{abstract}

Kata kunci : program power point, presentasi, pemahaman siswa, TIK, SMP Negeri 1 Kabupaten Sorong 


\section{Pendahuluan}

Mata pelajaran Teknologi Informasi dan Komunikasi (TIK) merupakan mata pelajaran yang berfungsi sebagai alatteknologi dan informasi. Bahkan sangat bermanfaat untuk memecahkan berbagai macam masalah dalam kehidupan sehari-hari.Pada umumnya mata pelajaran teknologi dan informasi merupakan mata pelajaran yang disukai oleh siswa karena saat ini mata pelajaran tersebut merupakan materi yang baru berkembang di Indonesia bahkan tingkat dunia.

Teknologi Informasi dan Komunikasi (TIK) terdiri dari dua bagian yaitu teknologi informasi dan teknologi komunikasi. Teknologi informasi secara ringkas berarti teknologi untuk menghadirkan informasi atau secara lengkapnya segala hal yang berkaitan dengan proses, penggunaan sebagai alat bantu, manipulasi, dan pengelolaan informasi. Sementara teknologi komunikasi secara ringkas berarti teknologi yang memungkinkan manusia berkomunikasi dengan sesamanya secara lebih mudah. Secara lengkap arti dari teknologi komunikasi adalah segala hal yang berkaitan dengan penggunaan alat bantu untuk memproses dan mentransfer data dari perangkat yang satu ke lainnya (LKS 2006 : 56).

Karena itu teknologi informasi dan komunikasi adalah suatu kesatuan yang tidak terpisahkan yang mengandung pengertian luas tentang segala aspek yang terkait dengan pemrosesan, manipulasi, pengolahan, transfer/pemindahan informasi antar mediadengan menggunakan teknologi tertentu.

Teknologi informasi dan komunikasi sedemikian pentingnya dan mampu mengubah cara pandang manusia mengenai informasi.Maka dari itu untuk dapat mengetahui informasi secara lebih cepat dan akurat diperlukan sebuah alat yang canggih yang dinamakan komputer. Power point adalah salah satu software Microsoft Office yang digunakan untuk merancang / mendesain slide atau bahan-bahan presentasi.Dengan adanya program ini maka presentasi menjadi lebih menarik (Budiman, 2002 : 71). Program presentasi dipergunakan untuk menampilkan slide-slide, gambar-gambar, chart atau yang lain. Program ini sangat cocok untuk presentasi/ pemaparan suatu program dengan bentuk tampilan (show) yang menarik (Tim MGMP, 2008 ).

Pembelajaran Teknologi Informasi dan Komunikasi (TIK) dikelasVII semester II SMP Negeri 1 Kabupaten Sorongdiantaranya berkenaan dengan standar kompetensi mempraktikkan keterampilan dasar komputer, dan kompetensi dasar memahami kegunaan dari beberapa program aplikasi, serta indikator menjelaskan berbagai perangkat lunak (software) program aplikasi berbasis presentasi yang salah satunya adalah program power point.Dalam upaya untuk meningkatkan kemampuan siswa dalam menggunakan program power point ini, peneliti melakukan penelitian yang bertujuan untuk meningkatkan pemahaman siswa terhadap teori mengenai program power point serta untuk meningkatkan kemampuan siswa dalam menggunakan program power point melalui praktik membuat presentasi. Melalui penelitian dan penerapan strategi pembelajaran ini diharapkan minat dan hasil belajar siswa dalam pembelajaran TIK lebih meningkat, bahkan diharapkan siswa juga mampu mengaplikasikan kemampuan membuat presentasi dengan program power point tersebut dalam kegiatan pembelajaran di sekolah khususnya pada mata pelajaran TIK, umumnya pada mata pelajaran yang lain. Adapun bagi Guru, diharapkan dapat meningkatkan motivasi dan kreativitas dalam melaksanakan proses belajar mengajar di Laboratorium Komputer, serta menambah apresiasi baru dalam memacu prestasi belajar 
khususnya dalam pembelajaran TIK. Sedangkan bagi sekolah, diharapkan dapat meningkatkan kualitas pelayanan pendidikan kepada peserta didik.

Dalam proses belajar mengajar yang menjadi persoalan pokok bagaimana memilih dan menggunakan strategi belajar mengajar merupakan alat interaksi didalam proses belajar mengajar. Strategi yang digunakan harus menimbulkan aktivitas belajar yang baik, sehingga tujuan pembelajaran dapat tercapai secara maksimal.Untuk membantu memperoleh kemampuan di atas, ada beberapa hal yang perlu diperhatikan: (1) konsep dan prinsip belajar dan pembelajaran, (2) variabel strategi belajar mengajar, (3) berbagai jenis strategi belajar mengajar.

Banyak pengertian belajar telah dikemukakan oleh para ahli, salah satu diantaranya ialah menurut Gane dalam Udin S.Winatapura (1998: 23), bahwa belajar adalah satu prosesdimana suatu organisme berubah perlakuannya sebagai akibat pengalaman. Dari pengertian belajar tersebut terdapat tiga atribut pokok (ciri utama)belajar, yaitu proses perubahan prilaku dan pengalaman.

Dalam kesempatan ini kita akan membicarakan tentang kesiapan siswa untuk belajar serta secara pembelajarannya. Beberapa teori belajar yang sering digunakan dalam pembelajaran TIK. Untuk membuat efektifnya pengajaran serta persyaratan dasar agar berhasil, kita akan mencoba membuatkan rancangan pembelajaran TIK di SMP N 1 Kabupaten Sorongdengan memperhatikan teori-teori belajar dalam bentuk model-model pelajaran yangmemungkinkan.

\section{Metode Penelitian}

\subsection{Desain Penelitian}

Penelitian ini merupakan penelitian tindakan kelas. PTK ini dilakukan dalam 2 siklus dimana masing-masing siklus terdiri dari 4 tahapan yakni: perencanaan, tindakan, pengamatan dan refleksi.

\subsection{Subjek Penelitian}

Subjek dalam penelitian ini adalah siswa kelas VII semester II tahun pelajaran 2016/2017 SMP Negeri 1 Kabupaten Sorong.

\subsection{Lokasi dan Waktu Penelitian}

Penelitian dilaksanakan di SMP Negeri 1 Kabupaten Sorong pada tanggal 17 Februari 2017 untuk siklus I, dan tanggal 13 April 2017 untuk siklus II.

\subsection{Teknik Pengumpulan Data}

Teknik pengumpulan data yang digunakan dalam PTK ini adalah teknik tes dan observasi.

\subsection{Teknik Analisis Data}

Teknik analisis dalam penelitian ini dilakukan dengan cara mencatat nilai siswa, mencari nilai kumulatif dari tiap aspek, menghitung nilai perolehan dan menentukan persentase. Perhitungan persentase dengan rumus :

$$
\mathrm{NP}=\frac{R}{N k}
$$


Keterangan :

$\mathrm{NP}=$ Nilai persentase

$\mathrm{Nk}=$ Nilai komulatif

$\mathrm{R}=$ Jumlah responden

\section{Hasil Penelitian dan Pembahasan}

\subsection{Hasil Penelitian}

Dibawah ini adalah hasil pengamatan terhadap kegiatan siswa sebelum diadakan pebaikan siklus I dan siklus II pada mata pelajaran TIK standar kompetensimempraktikkan ketrampilan dasar komputer.Kompetensi dasar mengidentasifikasi berbagai komponen perangkat lunak komputer. Pengumpulan data dilakukan melalui observasi.

Tabel 1. Hasil Pengamatan Terhadap Kegiatan SiswaSebelum Tindakan

\begin{tabular}{lcccc}
\hline \multirow{2}{*}{ Aspek yang Diamati } & \multicolumn{3}{c}{ Hasil Observasi } & \multirow{2}{*}{ Jumlah } \\
\cline { 2 - 4 } & Kurang & Cukup & Baik & \\
\hline Membuka lembar kerja power point & 6 & 16 & 10 & 32 \\
Membuat slide & 8 & 13 & 11 & 32 \\
Keberanian bertanya & 23 & 4 & 5 & 32 \\
Keberanian menjawab pertanyaan & 24 & 5 & 3 & 32 \\
Kerjasama & 16 & 9 & 7 & 32 \\
\hline
\end{tabular}

Tabel 2. Hasil Pengamatan Terhadap Kegiatan Siswa pada Siklus I

\begin{tabular}{lcccc}
\hline \multirow{2}{*}{\multicolumn{1}{c}{ Aspek yang Diamati }} & \multicolumn{3}{c}{ Hasil Observasi } & \multirow{2}{*}{ Jumlah } \\
\cline { 2 - 4 } & Kurang & Cukup & Baik & \\
\hline Membuka lembar kerja power point & 4 & 18 & 10 & 32 \\
Membuat slide & 9 & 10 & 13 & 32 \\
Keberanian bertanya & 8 & 14 & 10 & 32 \\
Keberanian menjawab pertanyaan & 10 & 12 & 10 & 32 \\
Kerjasama & 9 & 13 & 10 & 32 \\
\hline
\end{tabular}

Tabel 3. Hasil Pengamatan Terhadap Kegiatan Siswa pada SiklusII

\begin{tabular}{lcccc}
\hline \multicolumn{1}{c}{ Aspek yang Diamati } & \multicolumn{3}{c}{ Hasil Observasi } & Jumlah \\
\cline { 2 - 4 } & Kurang & Cukup & Baik & \\
\hline Membuka lembar kerja power point & - & 10 & 22 & 32 \\
Membuat slide & 4 & 8 & 20 & 32 \\
Keberanian bertanya & 2 & 10 & 20 & 32
\end{tabular}


Keberanian menjawab pertanyaan

Kerjasama
3

$\begin{array}{ll}- & 10\end{array}$
24

22

Tabel 4. Persentase Data Nilai SiswaSebelum Tindakan

\begin{tabular}{cccc}
\hline No & Rentang Nilai & Jumlah Siswa & Persentase \\
\hline 1 & $45-54$ & 4 & $12,5 \%$ \\
2 & $55-64$ & 6 & $18,75 \%$ \\
3 & $65-74$ & 8 & $25 \%$ \\
4 & $75-84$ & 8 & $25 \%$ \\
5 & $85-94$ & 6 & $18,75 \%$ \\
6 & $95-100$ & - & - \\
\hline
\end{tabular}

Tabel 5. Persentase Data Nilai SiswaPada Siklus I

\begin{tabular}{cccc}
\hline No & Rentang Nilai & Jumlah Siswa & Persentase \\
\hline 1 & $45-54$ & 2 & $6,25 \%$ \\
2 & $55-64$ & 4 & $12,5 \%$ \\
3 & $65-74$ & 12 & $37,5 \%$ \\
4 & $75-84$ & 10 & $31,25 \%$ \\
5 & $85-94$ & 4 & $12,5 \%$ \\
6 & $95-100$ & - & - \\
\hline
\end{tabular}

Tabel 6. Persentase Data Nilai SiswaPada Siklus II

\begin{tabular}{cccc}
\hline No & Rentang Nilai & Jumlah Siswa & Persentase \\
\hline 1 & $45-54$ & - & - \\
2 & $55-64$ & - & - \\
3 & $65-74$ & 12 & $37,5 \%$ \\
4 & $75-84$ & 12 & $37,5 \%$ \\
5 & $85-94$ & 8 & $25 \%$ \\
6 & $95-100$ & - & - \\
\hline
\end{tabular}

Dari tabel diatas diketahui bahwa telah terjadi peningkatan hasil perbaikan pembelajaran. Sebelum perbaikan, siswa yang tuntas dengan nilai rata-rata 75 ada 8 siswa dari 32 siswa atau 25\%. Pada perbaikan siklus I meningkat menjadi 10 siswa dari 32 siswa 
atau $31,25 \%$. Kemudian pada perbaikan siklus II lebih meningkat lagi menjadi 12 siswa dari 32 atau $37,5 \%$.

Peningkatan hasil evaluasi pada mata pelajaran TIK dapat digambarkan dalam diagram batang di bawah ini :

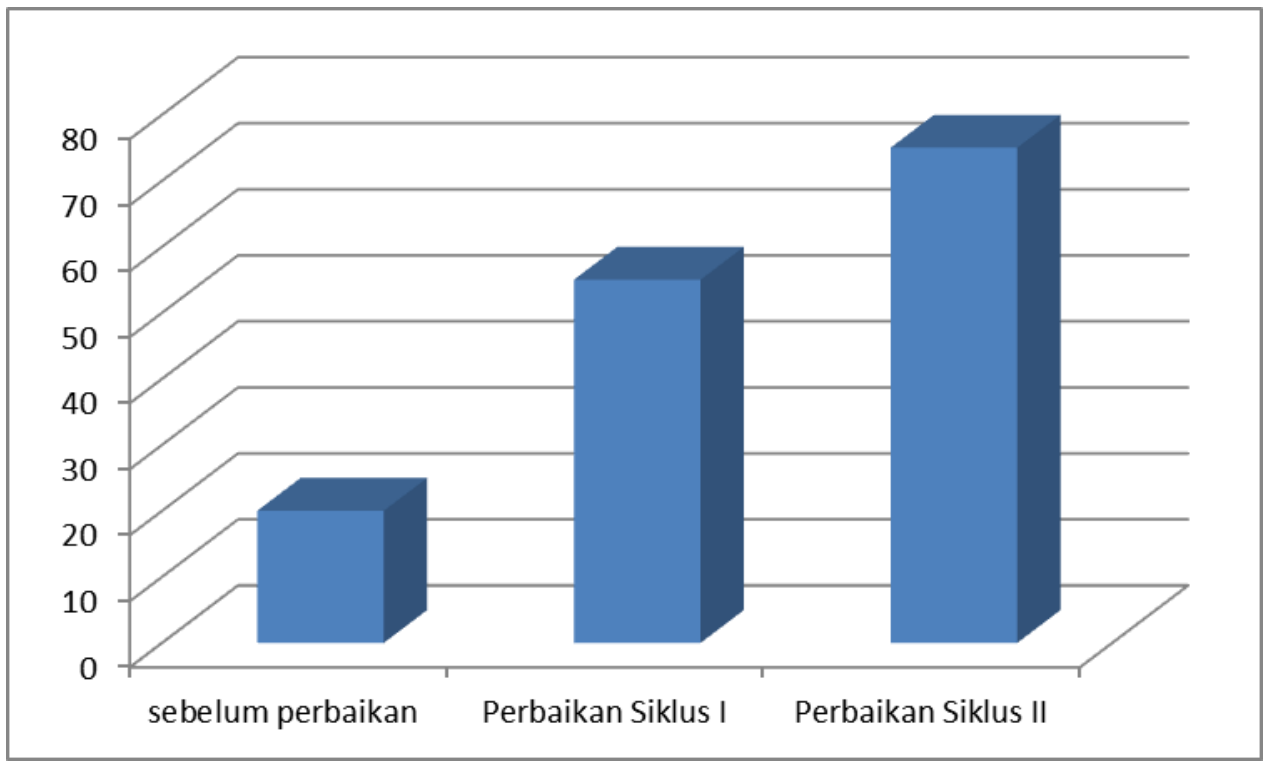

Gambar 1. Peningkatan Hasil Evaluasi Mata Pelajaran TIK

\subsection{Pembahasan}

\subsubsection{Sebelum Perbaikan Pembelajaran}

Dalam pembahasan hasil penelitian ini dapat dijelaskan bahwa pada proses pembelajaran mata pelajaran TIK tentang perangkat lunak program aplikasi berbasis presentasi. Kompetensi dasar mengidentifikasi berbagai komponen perangkat lunak komputer yang dilaksanakan pada kelas VII SMP Negeri 1 Kabupaten Sorong, sebelum diadakan perbaikan pembelajaran kurang berhasil, karena setelah diadakan refleksi oleh peneliti dan didiskusikan dengan teman sejawat dengan konsultasi dengan pembimbing kemudian diidentifikasi dan diketahui kekurangan dan kelemahan pada proses pembelajaran tersebut yaitu:

a. Guru hanya menggunakan metode ceramah dan tanya jawab

b. Siswa tidak diberi kesempatan untuk berperan aktif

c. Strategi pembelajaran yang efektif dan kooperatif belum dilaksanakan.

Hasil evaluasi menunjukkan keberhasilan siswa yang tuntas hanya 8 siswadari 32 siswa atau $25 \%$.

\subsubsection{Perbaikan Siklus}

Pada perbaikan pembelajaran Siklus I, kemudian diidentifikasi, dianalisa dan direfleksi dengan teman sejawat dikonsultasikan dengan pembimbing, ada beberapa hal yang perlu diperbaiki, diantaranya : 
1) Guru perlu menerapkan metode dan strategi pembelajaran dari metode ceramah dan tanya jawab diganti dengan Cooperative Learning.

2) Dengan menerapkan Cooperative Learning siswa lebih berperan aktif

Setelah proses perbaikan pembelajaran siklus I ternyata hasil tes formatif ada peningkatan yaitu siswa yang mencapai nilai ketuntasan 75 keatas sebanyak 10 siswa dari 32 siswa atau $31,25 \%$. Namun peningkatan itu masih belum menunjukkan keberhasilan yang diharapkan oleh peneliti, untuk itu peneliti menindaklanjuti dengan melakukan proses perbaikan pembelajaran pada siklus II.

\subsubsection{Perbaikan Siklus II}

Dalam perbaikan pembelajaran siklus II, peneliti berdiskusi dengan teman sejawat untuk merencanakan langkah-langkah yang harus dilakukan dan mengkonsultasikan dengan pembimbing dan menghasilkan beberapa langkah yang harus ditempuh antara lain :

1) Streategi pembelajaran yang digunakan pada siklus II adalah Cooperative Learningdengan pemanfaatan media pembelajaran yang kongkrit.

2) Siswa banyak diberi kesempatan lebih aktif

Dari hasil pelaksanaan perbaikan pembelajaran siklus II ternyata hasil tes formatif semakin meningkat. Hal ini terbukti siswa yang mencapai nilai ketuntasan 75 keatas sebanyak 12 siswa dari 32 siswa atau 37,5\%. Dengan demikian hasil penelitian yang dilaksanakan dalam proses perbaikan pembelajaran dalam dua siklus, dengan melalui PTK memperoleh hasil yang memuaskan dan sangat bermanfaat bagi peneliti untuk dapat digunakan pada masa mendatang.

\section{Simpulan dan Saran}

\subsection{Kesimpulan}

Perbaikan pembelajaran ternyata sangat diperlukan dalam proses pembelajaran. Dari hasil perbaikan yang telah dilaksanakan oleh guru dapat disimpulkan bahwa proses pembelajaran dengan menerapkan strategi pembelajaranCooperative Learning, serta mengoptimalkan media pembelajaran dapat lebih meningkatkan hasil belajar siswa khususnya pelajaran T I K tentang standar kompetensi melakukan pembuatan program aplikasi berbasis presentasi dalam pemecahan masalah perbandingan dengan skala, indikator memecahkan masalah skala di SMP Negeri 1 Kabupaten Sorong.

\subsection{Saran}

Guru hendaknya lebih mengembangkan kreativitas dalam mengajar termasuk dalam memilih strategi pembelajaran yang efektif. Menggunakan media pembelajaran secara optimal sehingga dapat memotivasi siswa dalam pembelajaran dan siswa tidak merasa bosan.Laporan yang penulis buat dapat dijadikan bahan diskusi dalam kegiatan kelompok kerja serta dapat dijadikan bahan referensi untuk langkah dalam mengambil kebijakan. 


\section{Daftar Pustaka}

Supriyanto. K T S P 2006.Teknologi Informasi \&Komunikasi. Semarang: Yudhistira Mulyadi Sumantri dan Syaodih. 2008. Perkembangan Peserta Didik. Jakarta: Universitas Terbuka.

L P K BUDIMAN.2002. WINDOWS + OFFICE.

TIM MGMP TIK Kota Semarang. 2009/2010. LKS TIK Kelas VII Semester II. Semarang: Sarana Ilmu.

TIM MGMP TIK Kota Semarang. 2010/2011. LKS TIK Kelas VII Semester II. Semarang: Sarana Ilmu. 